\title{
Sustainability in Brazilian floriculture: introductory notes to a systemic approach ${ }^{(1)}$
}

\author{
ANTONIO HÉLIO JUNQUEIRA ${ }^{(2)^{*}}$ and MARCIA DA SILVA PEETZ ${ }^{(3)}$
}

\begin{abstract}
The article aims at an introductory exploration of the theme of sustainability in Brazilian floriculture, both in its segment of cut flowers and foliage and in landscaping. The study is based on bibliographic review, data collection and interpretation on the recent performance of the flower and ornamental plants market in Brazil, with emphasis on the role played by the importation of genetic material from exotic species to support commercial activity in the country. From this phenomenon and the productive and distributive concentration of the flowers and plants in the State of Sao Paulo (Holambra, Santo Antônio de Posse, Campinas, Atibaia and Mogi das Cruzes), discusses the national homogenization of taste and consumption habits and requirements for adapting exotic species. In the end, the research points to future ways of investigating the potential of native species exploration in favor of better results for the environmental and socioeconomic sustainability of the floriculture and ornamental plants sector in Brazil.
\end{abstract}

Keywords: sustainability, native plants, ecological landscaping, consumption.

\section{RESUMO}

Sustentabilidade na floricultura brasileira: apontamentos introdutórios para uma abordagem sistêmica

$\mathrm{O}$ artigo visa à exploração introdutória do tema da sustentabilidade na floricultura brasileira, tanto no seu segmento de flores e folhagens de corte e envasadas, quanto no paisagismo. O estudo parte de revisão bibliográfica, coleta e interpretação de dados sobre o desempenho recente do mercado de flores e plantas ornamentais no Brasil, com ênfase no papel desempenhado pela importação de material genético de espécies exóticas para a sustentação da atividade comercial no país. A partir desse fenômeno e da concentração produtiva e distributiva das flores e plantas no Estado de São Paulo (Holambra, Santo Antônio de Posse, Campinas, Atibaia e Mogi das Cruzes), discute a homogeneização nacional do gosto e dos hábitos de consumo e as exigências ecológicas para a adaptação de espécies exóticas. A pesquisa aponta, ao final, caminhos futuros para a investigação do potencial da exploração das espécies nativas em favor de melhores resultados para a sustentabilidade ambiental e socioeconômica do setor de floricultura e plantas ornamentais no Brasil.

Palavras-chave: sustentabilidade, plantas nativas, paisagismo ecológico, consumo.

\section{INTRODUCTION}

Commercial floriculture is a dynamic and promising sector in Brazilian agribusiness, accounting for strong economic results and with percentage performance indicators positioned above the average obtained by other sectors of recent rural production. In 2017, the sector moved the amount of $\mathrm{R} \$ 6.9$ billion, at the end consumer level, with growth of just over $6 \%$ over the previous year, sustaining a favorable economic performance, despite the context of the economic and financial crisis which affects the country. By 2018, the estimated value for this productive chain is $\mathrm{R} \$ 7.2$ billion, an increase of $4 \%$ over the previous year (Table 1).

In the period from 2008 to 2011, the sector grew, on average, $8 \%$ to $10 \%$ per year in the quantities offered in the market and between $12 \%$ to $15 \%$ per year, in sales value. In 2012, the market grew between $7 \%$ and $8 \%$ in quantity and between $10 \%$ and $12 \%$ in marketed value. In 2013, the observed growth was between 7\% and $8 \%$, both in quantity and value. Since then, with the introduction and aggravation of economic problems and the exhaustion of the main sources of market expansion that had characterized the previous years - such as the entry of the supermarket segment into the retail distribution of flowers and ornamental plants in Brazil - the sector started to consolidate a trend of stabilizing growth in the range of $6 \%$ per year. More recently, as seen, the annual growth rate has become more subdued, falling to $4 \%$.

This article aims at first detailing the composition of the consumption of Brazilian floriculture in its component subsectors, emphasizing the high level of geographic and economic concentration of the activity and the consequent homogenization of the taste and habits of consumption

(2) Universidade Anhembi Morumbi (UAM), São Paulo-SP, Brazil *Corresponding author: helio@hortica.com.br

${ }^{(3)}$ Hórtica Consulting and Market Intelligence, São Paulo-SP, Brazil.

Licensed by CC BY 4.0 
throughout the country. It then assesses the degree of external dependence on the importation of exotic genetic materials, pointing to the ecological and environmental costs of this consolidated route in the national floricultural model.

It follows from a bibliographical review, signaling to critical aspects of the current model and to the advantages of a more desirable participation of the use and exploitation of native species, both for the production of cut flowers and plants and for landscaping and gardening. Finally, it seeks to relate some guidelines for the future investigation of the theme.

\section{FLORICULTURE IN BRAZIL: GEOGRAPHICAL CONCENTRATION AND EXTERNAL DEPENDENCE OF VARIETAL GENETICS}

Mainly concentrated in the domestic consumer market, which has been directing $99.3 \%$ of all marketed value since 2015, Brazil's chain of flowers and ornamental plants covers an area of 13,468 thousand hectares, exploited by 7,800 growers and approximately $350 \%$ of native and exotic species and cultivars, about $10 \%$ of the total number of plant species present in the country and already known (JUNQUEIRA and PEETZ, 2017a).

Table 1. BRAZIL. Evolution of total market and per capita consumption of flowers and ornamental plants, 2010-2017

\begin{tabular}{|c|c|c|}
\hline Year & $\begin{array}{c}\text { Total market } \\
\text { (R\$ billion) }\end{array}$ & $\begin{array}{c}\text { Per capita consumption } \\
\text { (R\$) }\end{array}$ \\
\hline 2010 & 3.8 & 19.5 \\
\hline 2011 & 4.4 & 22.3 \\
\hline 2012 & 4.8 & 24.1 \\
\hline 2013 & 5.2 & 25.9 \\
\hline 2014 & 5.6 & 27.6 \\
\hline 2015 & 6.1 & 29.9 \\
\hline 2016 & 6.5 & 31.6 \\
\hline 2017 & 6.9 & 33.2 \\
\hline $2018 *$ & 7.2 & 34.3 \\
\hline
\end{tabular}

Source: Hórtica Consulting and Market Intelligence, 2018. * Prediction; data subject to review.

Commercial floriculture practiced in Brazil is concentrated in São Paulo State (48.9\%), particularly in the geographical regions around the municipalities of Atibaia (Atibaia, Mogi das Cruzes, Suzano and others) and Holambra (Holambra, Santo Antonio de Posse, Campinas and others). From these regions are organized supply flows of short, medium and long distances, that manage to bring the flowers and ornamental plants of São Paulo at least to the capitals and main poles of consumption of the whole Brazil.

As an important historical consequence of this concentration in Brazil - in which few poles of production sustain the supply flows of large territorial ranges - over the last few decades there has been a remarkable homogenization of consumption habits (JUNQUEIRA and PEETZ, 2008b, 2017 b). In this context, regional flowers and plants have lost the importance and preference of their former consumers, given the quality, standard, abundant and regular offerings of products from the most professional and competitive floriculture of the South and Southeast regions of Brazil. Of particular note is São Paulo State, and more particularly, the floriculture practiced by the associated producers and members of the Veiling Holambra Cooperative and the Cooperflora Cooperative, located in the cities of Santo Antonio de Posse and Holambra, respectively.
Historically, the richness and diversity of the Brazilian flora have dazzled colonizers, botanists, artists and travelers, leaving behind it ample documentary and iconographic records, which until today attest to the fascination exercised (HOEHNE, 1930). It is estimated that Brazil has between $15 \%$ and $20 \%$ of the total known plants of the planet (ROMÃO et al., 2015), which add up to 50,000 species (MITTERMEIER et al., 1997). Across the country, it is estimated that between 5,000 and 6,000 species of trees have ornamental potential for landscaping and urban planting (MELLO FILHO, 1995). Brazil also has around 480 species of palm trees. However, native genera such as Geonoma, Mauritia and Bactris are cultivated abroad, but are practically ignored commercially in Brazil (LEAL and BIONDI, 2006). Predominant taste and commercial interest in exotic species such as Arcantophoenys sp. (seafortia), Crysalidocarpus sp. (areca), Caryota spp. (cariota) and Livistona spp. (livistona), among others. This reality follows and portrays the long and intense process of introducing exotic species into the country, especially from the Empire (DEAN, 1992; PRESTES, 2000).

Thus, over time, the consumption of flowers and ornamental plants was highly concentrated on a very small range of products, practically indistinct from the South to the North of Brazil and especially based on the 
taste introduced by colonizers and immigrants of different nationalities (JUNQUEIRA and PEETZ, 2017a). As early as the mid-1970s, when Brazilian floriculture was not yet consolidated in the highly concentrated and specialized business model it currently displays, Brazilian experts already registered the low interest of the population, of all social classes, by native species. This is what can be observed, for example, in the writings of Carlos Toledo Rizzini, renowned researcher dedicated to the Brazilian flora register (RIZZINI, 1977).

Currently, the market for the production chain of flowers and ornamental plants in Brazil is mainly composed of the segment of ornamental plants for landscaping and gardening, which accounts for $42 \%$ of the total financial movement with these goods. The second place in the sectoral ranking is occupied by the sector of cut flowers and foliage, with a relative percentage participation of $34 \%$, followed in the third and last position by the flower and bottled plants, with $24 \%$. The main species of ornamental plants cultivated and commercialized in Brazil for the landscaping and gardening sector belong to the groups of trees, shrubs and palm trees (74\%), ornamental fodder $(14 \%)$ and other small and medium sized plants (12\%). The main cut flowers cultivated in Brazil today are: roses (30\%), chrysanthemums (15\%), lisianthus (12\%), lily (7\%) and gerbera $(6 \%)$. As for flowers and ornamental plants, the six main species are in descending order of relative importance: orchids $(14 \%)$, lily $(7.5 \%)$, chrysanthemum $(7 \%)$, kalanchoe $(6.4 \%)$, violet $(6 \%)$ and bromeliad $(6 \%)$ (JUNQUEIRA and PEETZ, 2017a).

It is not difficult to note that all these main species grown, commercialized and consumed in Brazil are exotic and come from improved genetic material adapted and developed abroad, mainly by companies from Europe (Holland, Germany and others) and Asia (Japan, Thailand and others). As seen, even in the palm segment, where the country has a remarkable diversity of aesthetic interest, the importation and exploitation of exotic species is expressively relevant. It is also worth noting that for some native products of Brazil or Tropical America - such as anthurium (Anthurium sp.), bromeliads, alstroemeria (Alstroemeria x hybrida Hort.), solidago (Solidago sp.) and others - genetic improvement has made them highly dependent of special conditions of cultivation (temperature, irrigation, fertilization, photojournalism), assimilating them to other exotic species.

Thus, the excessive homogenization of the preferences of ornamental species throughout the country has required the installation of species in climatic and ecological environments to which they are not fully adapted. As a result, spending on inputs and consumption of renewable and non-renewable natural resources has become environmentally unsustainable and socioeconomically perverse. Such phenomena are observed not only for commercial floriculture focused on the production of cut flowers and foliage and bottled but also in the landscaping industry.
The use of exotic exotic species in climatic and ecological conditions that are in conflict with the natural space of the different Brazilian biomes and regions has caused great distortions in the urban landscape projects. In arid or excessively hot environments in the Northeast, North and Central West, for example, the option of using temperate or subtropical species will require great efforts, both for resilience of the plants themselves and for the technicians, to guarantee their survival. This is the case, for example, of urban landscaping in Palmas (TO), based on the intense use of lawns, trees, shrubs, exotic and little adapted annual plants, demanding, therefore, the application of large quantities of chemical and in irrigation water, often applied without the aid of adequate and minimally efficient technology. The results have been disastrous both from the environmental point of view and from the landscape economy, considering the high levels of plant losses and the low aesthetic result of the projects (JUNQUEIRA and PEETZ, 2009). Similar situations are also observed in other Brazilian capitals, such as in Natal (RN), aggravated by the unavailability of tank cars and minimum equipment for landscape irrigation (JUNQUEIRA and PEETZ, 2008).

To support this high degree of concentration in the use and economic exploitation of exotic species, Brazilian floriculture has become progressively dependent on the importation of materials from the foreign varietal genetic industry. In recent years, significant increases can be observed in the importation of propagating material and plant propagation. Table 2 shows that in the period from 2005 to 2017 imports of these goods increased from US\$5.4 million to US\$40.2 million, not including flower seeds and ornamental plants, for which there are no official statistics available.

In the same period, the percentage participation of the group in total Brazilian imports of floricultural products increased from $69.11 \%$ to $82.63 \%$ (Table 1). All the segments suffered quantitative fluctuations in the analyzed period, which showed fluctuations according to different conditions of the Brazilian market, but mainly due to the variations in the exchange power of the national currency in the exchange rate relationships. It should be noted, however, the notable expansion of the import market of orchid seedlings for the production of flowers packaged for consumption in the domestic market, especially phalaenopsis, denphal and cymbidium, among others.

From the point of view of the international market, the Brazilian business floriculture specialized in the multiplication of propagating material, which are reexported to their sources of origin in significant quantities. In this case, it is particularly noteworthy that amaryllis (Hyppeastrum sp.), for which $60 \%$ of the production goes on export and gladiolus (Gladiolus x grandiflorus), which sends $40 \%$ of the production abroad (TOMBOLATO et al., 2013). However, significant portions of this genetic material is directed to the final production of goods for domestic consumption. 
Table 2. BRAZIL. Evolution of the percentage share of imports of propagating material over total imports of flowers and ornamental plants, 2005-2017, in US\$.

\begin{tabular}{|c|c|c|c|c|c|c|c|}
\hline \multirow[b]{2}{*}{ Year } & \multirow[b]{2}{*}{$\begin{array}{c}\text { Total } \\
\text { imports } \\
\text { (1) }\end{array}$} & \multirow[b]{2}{*}{ bulbs } & \multicolumn{3}{|c|}{ young plants/seedlings } & \multirow[b]{2}{*}{$\begin{array}{l}\text { Genetic material } \\
\text { imports }\end{array}$} & \multirow[b]{2}{*}{$\begin{array}{c}\% \\
(2 / 1)\end{array}$} \\
\hline & & & orchids & $\begin{array}{c}\text { other } \\
\text { ornamental } \\
\text { plants }\end{array}$ & $\begin{array}{l}\text { others } \\
\text { plants }\end{array}$ & & \\
\hline 2005 & $5,402,475$ & $1,812,713$ & 790 & 438 & 693 & $3,733,595$ & 69.11 \\
\hline 2006 & $8,543,844$ & $2,767,970$ & $1,059,351$ & 701 & $1,943,408$ & $6,471,348$ & 75.74 \\
\hline 2007 & $10,515,608$ & $4,131,421$ & $1,385,061$ & $1,118,041$ & $1,933,390$ & $8,567,913$ & 81.48 \\
\hline 2008 & $13,927,968$ & $4,692,065$ & $2,382,694$ & $1,722,709$ & $2,228,263$ & $11,025,731$ & 79.16 \\
\hline 2009 & $19,814,223$ & 8.259 .718 & $2,897,036$ & $2,390,722$ & $3,002,384$ & $16,549,860$ & 83.53 \\
\hline 2010 & $24,961,913$ & $7,329,961$ & $4,205,373$ & $3,089,763$ & $4,152,504$ & $18,777,601$ & 72.53 \\
\hline 2011 & $34,345,096$ & $9,725,273$ & $6,746,987$ & $3,472,053$ & $6,109,740$ & $26,054,053$ & 75.86 \\
\hline 2012 & $39,475,606$ & $9,878,119$ & $8,869,938$ & $4,075,719$ & $7,652,598$ & $30,476,374$ & 77.20 \\
\hline 2013 & $41,939,533$ & $10,859,298$ & $10,739,159$ & $4,367,275$ & $6,618,362$ & $32,584,094$ & 77.69 \\
\hline 2014 & $46,474,091$ & $9,559,381$ & $15,520,527$ & $4,089,455$ & $7,053,900$ & $36,223,263$ & 77.94 \\
\hline 2015 & $39,750,397$ & $7,354,684$ & $13,626,032$ & $2,796,677$ & $7,216,261$ & $30,993,654$ & 77.97 \\
\hline 2016 & $31,567,504$ & $5,810,213$ & $11,109,761$ & $1,639,966$ & $6,375,283$ & $24,935,223$ & 78.99 \\
\hline 2017 & $40,195,092$ & $6,632,698$ & $17,165,282$ & $1,685,992$ & $7,731,141$ & $33,215,113$ & 82.63 \\
\hline
\end{tabular}

Source: Hórtica Consulting and Market Intelligence, 2018, from basic statistics of the Ministry of Development, Industry and Foreign Trade - Secretariat of Foreign Trade - ALICEweb2, 2018.

\section{SUSTAINABILITY IN THE LANDSCAPE CHAIN: AN INTRODUCTION}

In contemporary times, the word sustainability has been incorporated into daily life and has been used with prodigality, although most of the discourses have renounced the need to specify the term better. This fact stems from the character of inconclusiveness and intense socio-political fluctuation of its meaning, socially still under construction, given its unquestionable complexity.

However, although there is no consensus on the definition of sustainability in today's human societies, it can be seen that in all the versions proposed for the debate on this theme, the question of revision and redefinition of production patterns and of socially dominant consumption emerge with centrality.

In the same way, the concept of "sustainable development" does not find consensual basis for its better precision. Anthony Giddens in "Climate Change Policy", published in Brazil in 2010, questions the contradictory meanings between the terms "development" - linked to dynamism and change - and "sustainable", in turn, correlated with continuity and balance. He says, "One of the answers to the elusive nature of this concept was simply to avoid defining it and instead replacing it with a cluster of goals" (GIDDENS, 2010, p.88). It is worth noting that the term "sustainable development" was socially introduced from the 1987 World Commission on Environment and Development Report (Our Commom Future, 1987), chaired by former Norwegian Prime Minister Gro Harlem
Brundtland, which became known worldwide as the Brundtland Report (GIDDENS, 2010).

Despite the controversies and inaccuracies, the concept of sustainable development points to advances, especially with regard to its institutionalization, signaling the social consolidation of a new ethic possible in the tense relationship between society and nature. When specifically targeting landscaping, concern for sustainability requires approaches to issues such as: (i) preservation, protection and enhancement of biodiversity, biomes and ecosystems, and local and regional landscape identities; ii) economics of renewable and non-renewable natural resources and iii) socio-economic and cultural development of the communities involved.

At the international level, the trend towards exploitation, use and preservation of native species, especially in landscaping, has been observed and registered since at least the early 1990s and in some cases supported and supported by specific legislation (BAÑERAS, 1999). In Brazil, the landscaper Burle Marx (1909-1994) is consensually identified as the pioneer and main responsible for the reintroduction and revaluation of the use of native species in his projects, since the 1930s (FROTA et al., 2009) . However, their teachings were not generalized and national landscaping also followed the path of homogenizing the use of exotic species and monotony, despite the immense ecological variability and biodiversity present.

In the last decades, however, there has been a significant increase in the interest and number of expeditions carried out for purposes of collecting and identifying species of 
the Brazilian flora, especially in the Amazon (SILVA and SILVA, 1998; ALBERNAZ and AVILA-PIRES, 2009; COELHO et al., 2015). In this paper, a considerable part of the new vegetables found have unquestionable value for floriculture and regional landscaping.

It should be noted that a certain impulse in the national production of national tree species has been guaranteed since the application of Law 12,651/2012 (as amended by Law No. 12,727/2012), which provides for the protection criteria of native vegetation (BRASIL, 2012) and that revoked the previous device, known as the Forest Code (Law No. 4,771/1965). Thus, in recent years, it is already registered in the country the existence of 1,276 nursery producers of native forest species, located mainly in São Paulo (369), Paraná (110), Pará (106) and Santa Catarina (88) states have been registered in the country in recent years (SILVA et al., 2015).

Ecologically based landscaping represents an important action for the conservation of the original characteristics of the landscapes and the cultural and ethnographic references of the different regions and biomes (DANSEREAU, 1999). In addition to conservation, ecological landscaping can also be an element in the recovery of degraded ecosystems (CHACEL, 2001). In these initiatives, the use of native plants in their community correlations with other plant and animal species constitutes the visceral essence of the projects.

Among the advantages of using native species are: i) their original ecological adaptation to soil, climate, temperature, pluviometric regimes and luminosity, among other factors; ii) low levels of investment and maintenance costs, given the natural resilience of the species in their own environment and, iii) their symbiotic and cooperative relationships with other plant species and local fauna.

In this context, several researchers have been dedicating so much to the creation of parameters for the identification of native species with ornamental potential (CHAMAS and MATTHES, 2000; HEIDEN et aol., 2006; LEAL and BIONDI, 2006; STUMPF et al., 2007), in the study of components of native floras promising for the segment in different biomes (BARROSO et al., 2007; CARADIN et al., 2011; ROMÃO et al., 2015; GRANEMANN et al., 2017). The Table 3 lists some desirable characteristics for these species and the main advantages associated with them.

Table 3. Characteristics and advantages of the use of native species in landscaping.

\begin{tabular}{|c|c|}
\hline Desirable characteristics & Benefits \\
\hline $\begin{array}{l}\text { Aesthetic morphological attributes } \\
\text { (color, shape, size, texture etc.). }\end{array}$ & $\begin{array}{l}\text { Valuation of regional diversity and specificities.Agroecological } \\
\text { education of the public. }\end{array}$ \\
\hline $\begin{array}{l}\text { Phenological attributes } \\
\text { (periods and durations of flowering, fruiting etc.). }\end{array}$ & $\begin{array}{l}\text { Viability of sequencing of desirable aesthetic results (sequential } \\
\text { blooms of different species, seasonal shading, pollen and fruits } \\
\text { to attract and protect species of insects and birds etc.) }\end{array}$ \\
\hline $\begin{array}{l}\text { Ecological interactions and good responses to intercropping } \\
\text { with groups of other native species. }\end{array}$ & $\begin{array}{l}\text { Direct and indirect benefits to local / regional flora and fauna } \\
\text { (attraction, shelter and protection of other species). } \\
\text { Protection of local / regional biodiversity. }\end{array}$ \\
\hline $\begin{array}{l}\text { Adaptability and efficiency for landscape restoration of } \\
\text { degraded environments. }\end{array}$ & $\begin{array}{l}\text { High level of response in landscape regeneration. } \\
\text { Cost reduction of installation and maintenance of regenerative } \\
\text { landscaping projects. }\end{array}$ \\
\hline $\begin{array}{l}\text { Rusticity, resistance to pests and diseases and } \\
\text { adaptation to the environment. }\end{array}$ & $\begin{array}{l}\text { High energy efficiency index. } \\
\text { Low maintenance cost. } \\
\text { Low demand for the use of inputs (pesticides and fertilizers) } \\
\text { and irrigation. } \\
\text { Resilience. } \\
\text { Ease of use. }\end{array}$ \\
\hline Reproductive and / or propagation and cultivation facilities. & $\begin{array}{l}\text { Technical and economic viability for projects. } \\
\text { Viability of production in local and regional nurseries by small } \\
\text { family farmers. }\end{array}$ \\
\hline
\end{tabular}

As main obstacles to the development of ecological landscaping in Brazil, the following factors are frequently observed: i) unavailability of native species in local and regional nurseries; ii) low agronomic quality, lack of commercial standards for plant size, pruning and conduction, defective root formation etc.; iii) irregularity and inconstancy of supply in the market (JUNQUEIRA and PEETZ, 2009).
In Brazil, there is a strong lack of supply of native products by local nurseries, which makes it impossible, in many cases, to implement and effectively implement projects designed with the intention of the best landscape offices in the country. It is recorded that important works, such as the landscaper Rosa Kliass, for Mangal das Graças in Belém (PA) had to be changed several times due to the total impossibility of obtaining the vegetables originally 
specified in their project. Similar situations were also registered for important residential condominiums in Manaus (AM) (JUNQUEIRA and PEETZ, 2009).

In fact, professional, well-trained and well-intentioned nurseries have not been able to market natural products from their regions, to the cultivation and care of which they sometimes dedicate themselves for years or decades. The main reason for the stranding of the goods is the lack of knowledge of the landscapers about the technical and ornamental potential of these species. There are reports of massive destruction of species rescued and reproduced in nurseries, which had to be discarded, to give space to exotic species with a higher level of commercial acceptance and interest in the market. This is the case, for example, in relation to important ornamental nurseries in the State of Goiás, especially with regard to the native regional palms of the Brazilian Midwest (Personal information obtained by the authors of the Goian nurseryman João Teles, in April 2011).

To overcome or minimize such problems, it is of fundamental importance to increase the knowledge, information, social visibility and availability of these plants, rescuing the cultivation and production of native species with ornamental application potential. The prospection of new ornamental plants, from the native species, represents great potential of production and commercialization both for the domestic market and for export (HEIDEN et al., 2006).

\section{SUSTAINABILITY IN CUTTING AND POTTED FLOWERS AND PLANTS: INTRODUCTORY ASPECTS}

The consumption of flowers and ornamental plants, all over the world, is volatile, subject to cycles of fashion and permanent search for novelties. To suit it, producers seek to keep up-to-date and constantly search for information on trends in fashion, consumption and the launching of new species, hybrids and varieties. In the flower market, products lose interest quickly and wear out, especially from the creation and circulation of stigmas such as "out of fashion", "products for funeral ceremonies", "rustics" among others. Aware of this, the ornamental plant genetics industry has been engaged in launching new products, or new names and concepts for old products. Around the world, the ornamental horticulture sector faces strong and permanent pressures for the production of products of ever higher quality, in sustainable ways, and at decreasing prices to final consumers. It is in practice impossible to undertake in this context without the adoption of increasingly advanced technologies in productive efficiency and saving of environmental, material, financial and human resources. Under conditions of water restriction, such as those that have been repeated in the main national floricultural zones in recent years, as well as the increasing costs of imported inputs - fundamental for the conduction of floral production in Brazil - the adoption of technological solutions increasingly advanced become essential (JUNQUEIRA and PEETZ, 2016).
However, the national floricultural activity is not homogeneous. On the contrary, there are immense disparities and technological systems of cultivation and commercialization that vary according to macro-regional areas and vocations. They are also differentiated according to segments (cut flowers, potted plants, landscaping and gardening), climatic and ecological conditions (tropical, subtropical, temperate), business culture and socioeconomic level of producers, besides the dynamics and potentials of consumer markets etc.

Even for the most advanced poles in floriculture, the technological challenge still imposes itself with centrality, requiring new investments and decisive action of the products in favor of competitive innovation and the integral attention to the new demands, demands and expectations of the distribution segments - increasingly displaced to selfservice - and consumers always mutant in their needs and desires (JUNQUEIRA and PEETZ, 2016).

From the point of view of sustainability, the use of irrigation emerges as one of the central aspects of concern. The water crisis that affected the South, Southeast and part of the Northeast between 2014 and 2016, evidenced the high level of vulnerability of the activity with massive losses of flowers and ornamental plants in the main poles of production. In addition to the death of the vegetables in the field, the sector faced the reduction of new landscape contracts, since the irrigation possibilities of the plants were also very limited in the urban environment. These phenomena forced producers to quickly seek solutions for water saving and reuse, rainwater harvesting and storage, and changes in irrigation patterns in production, especially of flowers and bottled foliage. In the latter case, there was a significant increase in the option for flood irrigation in the cultivation of anthuriums, lilies, calanchoes and calandivas among other species cultivated in pots, especially in the region of Holambra (SP).

\section{FINAL CONSIDERATIONS}

It can be affirmed that the Brazilian business floriculture has behaved, over time, as an innovative and technologically responsive segment to the new trends, demands and expectations of the markets. At the same time, however, the efficiency and competitiveness of floriculture and ornamental plants require greater and increasing levels of attention and investment in new technologies, especially based on the achievement of farm sustainability. The following topics point to relevant points in future research agendas in researching this topic:

i. Identification and valorization of native species with ornamental potential in their habitats and natural biomes;

ii. Adequacy of Brazilian legislation on the exploitation of biodiversity;

iii. Regionalization of production, with a focus on increasing the supply of employment opportunities and occupation of local and / or regional labor force, reducing transport flows of medium and long distances and reducing the emission of environmental pollutants; 
iv. Integration and exchange of information among the various agents of the Productive Chain of Flowers and Ornamental Plants throughout Brazil, on current and future offers and demands of native plant products;

v. Strengthening of regional identities in Brazilian landscaping and preservation of natural landscapes;

vi. Increased regenerative landscaping throughout the country.

vii. Application of the principles of ethnobotany as a form and instrument for the retrieval of information, memories and knowledge of traditional populations regarding the value and use of different ornamental species native or exotic adapted for a long time.

The production of flowers and ornamental plants in Brazil represents a highly promising and strategic activity, since it allows the economically profitable exploitation of small agricultural areas and close to large urban conglomerates and, at the same time, the productive incorporation of large contingents of workers, especially women and the elderly. It also aims to serve an unsatisfied, avid and absorbing market of quality products at affordable prices. In this set of advantages, however, it is necessary to undertake with innovation, technology and good productive and commercial practices so that success is guaranteed, on a sustainable basis, not only from the ecological and environmental point of view, but also socioeconomic.

\section{REFERENCES}

ALBERNAZ, A.L.K.M.; AVILA-PIRES, T.C.S. (Orgs.). Espécies ameaçadas de extinção e áreas críticas para a biodiversidade no Pará. Belém: Museu Paraense Emílio Goeldi, 2009. 60p.

BAÑERAS, J.C. Tendências no paisagismo. Revista Brasileira de Horticultura Ornamental, v.5, n.2, p. 9396, 1999.

BARROSO, C.M.; KLEIN, G.N.; BARROS, I.B.I.; FRANKE, L.B.; DELWIG, A.B. Considerações sobre a propagação e o uso ornamental de plantas raras ou ameaçadas de extinção no Rio Grande do Sul, Brasil. Revista Brasileira de Horticultura Ornamental, v.13, n. 2, p. 91-94, 2007. DOI: https://doi.org/10.14295/rbho.v13i2.210

BRASIL. Lei no 12.651, de 25 de maio de 2012. Dispõe sobre a proteção da vegetação nativa e dá outras providências. Brasília: Congresso Nacional, 2012.

LEAL, L.; BIONDI, D. Potencial ornamental de espécies nativas. Revista Científica Eletrônica de Engenharia Florestal, n.8, 2006.

CARADIN, L.; SIMINSKI, A.; REIS, A. (Eds.). Espécies nativas da flora brasileira de valor econômico atual ou potencial. Plantas para o futuro - Região Sul. Brasília: DF: Ministério do Meio Ambiente, 2011.
CHACEL, F. Paisagismo e ecogênese. Rio de Janeiro: Editora Fraiha, 2001. 143p.

CHAMAS, C.C.; MATTHES, L.A.F. Método para levantamento de espécies nativas com potencial ornamental. Revista Brasileira de Horticultura Ornamental, v.6, n.1/2, p.53-63, 2000. DOI: https://doi.org/10.14295/rbho. v6il.63

COELHO, M.A.N.; COSTA, D.P.; MARTINELLI, G.; MORAES, M.A. FORZZA, R.C. Expedições às montanhas da Amazônia. Rio de Janeiro: Andrea Jakobsson Estúdio Editorial Ltda., 2015. 244p.

DANSEREAU, P. A terra dos homens e a paisagem interior. Belém: Universidade Federal do Pará/ Núcleo de Altos Estudos Amazônicos, 1999. 156p.

DEAN, W. Botânica e a Política Imperial: introdução e adaptação de plantas no Brasil Colonial e Imperial. São Paulo: Instituto de Estudos Avançados, Universidade de São Paulo, 1992. 20p.

FROTA, L.C.; CAVALCANTI, L.; ZAPPA, R. Burle Marx, uma experiência estética: paisagem e pintura. Rio de Janeiro: 19 Design, 2009. 264p.

GIDDENS, A. A política da mudança climática. Rio de Janeiro: Zahar, 2010. 314p.

GIULIETTI, A.M.; HARLEY, R.M.; QUEIROZ, L.P.; WANDERLEY, M.G.L.; VAN DEN BERG, C. Biodiversidade e conservação das plantas no Brasil. Megadiversidade, v.1, p.52-62, 2005.

GRANEMANN, F.S; SANTOS, K.L.; GRANEMANN, F.; STEINER, N. Caracterização de espécies nativas com potencial ornamental de ocorrência na região de Curitibanos, SC. Agropecuária Catarinense, v.30, n.1, p.79-83, 2017.

HEIDEN, G.; BARBIERI, R.; STUMPF, E.R.T. Considerações sobre o uso de plantas ornamentais nativas.

Revista Brasileira de Horticultura Ornamental, v.12, n.1, p. 2-7, 2006. DOI: https://doi.org/10.14295/rbho. v12i1.60

HOEHNE, F.C. As plantas ornamentaes da flora brasílica, e o seu papel como factores da salubridade publica, da esthética urbana e artes decorativas nacionaes. São Paulo: Secretaria da Agricultura, Industria e Commercio, 1930. 231p.

JUNQUEIRA, A.H.; PEETZ, M.S. Brazilian consumption of flowers and ornamental plants: habits, practices and trends. Ornamental Horticulture, v.23, n.2, p.178-184, 2017a. DOI: https://doi.org/10.14295/oh.v23i2.1070 
JUNQUEIRA, A.H.; PEETZ, M.S. Cadeia Produtiva de Flores e Plantas Ornamentais da Grande Natal (RN). Natal: Sebrae RN, 2008a.

JUNQUEIRA, A.H.; PEETZ, M.S. Estudo sobre a competitividade e eficiência da cadeia da floricultura da Amazônia. Manaus: Sebrae AM, 2009.

JUNQUEIRA, A.H.; PEETZ, M.S. Intellectual property rights in Brazilian floriculture: innovations for the growth and development of the market. Ornamental Horticulture, v.23, n.3, 296-306, 2017b. DOI: https://doi.org/10.14295/ oh.v23i3.1071

JUNQUEIRA, A.H.; PEETZ, M.S. Mercado interno para os produtos da floricultura brasileira: características, tendências e importância socioeconômica recente. Revista Brasileira de Horticultura Ornamental, v.14, n.1, p.3752, 2008b. DOI: https://doi.org/10.14295/rbho.v14i1.230

JUNQUEIRA, A.H.; PEETZ, M.S. Tecnologia no cultivo de flores no Brasil. Anuário da Agricultura Brasileira Agrianual 2016, Informa Economics FNP, p.282-284, 2016.

MELLO FILHO, L.E. Botânica e arquitetura ou, segundo a ordem alfabética, arquitetura e botânica. A Lavoura, n.612, p.42-43, 1995.

MITTERMEIER, R.A.; GIL, P.R.; MITTERMEIER, C.G. Megadiversity: earth's biologically wealthiest nations. México: CEMEX/Agrupación Sierra Madre, 1997. 501p.

PRESTES, M.E.B. A investigação da natureza no Brasil colônia. São Paulo: Annablume/Fapesp, 2000. 154p.
RIZZINI, C.T. Plantas ornamentais. Rio de Janeiro: IBGE. 70p.

ROMÃO, R.; MARTINELLI, G.; CREPALDI, I.; MARTINEZ-LABORDLE, J.B. Brazilian diversity for ornamental use anda conservation. Crop Breeding and Applied Biotechnology, n.15, p.100-105, 2015.

SILVA, A.P.M.; MARQUES, H.R.; SANTOS, T.V.M.N.; TEIXEIRA, A.M.C.; LUCIANO, M.S.F.; SAMBUICHI, R.H.R. Diagnóstico da produção de mudas florestais nativas no Brasil. (Relatório de Pesquisa). Brasília: IPEA, 2015. 51p.

SILVA, J.B.F.; SILVA. M.F.F. Orquídeas nativas da Amazônia brasileira (gênero Catasetum L.C. Rich. ex Kunth). Belém: Museu Paraense Emílio Goeldi, 1998. $121 \mathrm{p}$.

STUMPF, E.R.T.; HEIDEN, G.; BARBIERI, R.L.; FISCHER, S.Z.; NEITZKE, R.S.; ZANCHET, B.; GROLLI, P.R. Método para avaliação de potencialidade ornamental de flores e folhagens de corte nativas e não convencionais. Revista Brasileira de Horticultura Ornamental, v.13, n.2. p.143-148-52, 2007. DOI: https:// doi.org/10.14295/rbho.v13i2.219

TOMBOLATO, A.F.C.; UZZO, R.P.; JUNQUEIRA, A.H.; PEETZ, M.S.; STANCATO, G.C. Geophyte research and production in Brazil. In: KAMENETSKY, R.; OKUBO, H. Ornamental geophytes: from basic science to sustainable production. Boca Raton, FL, EUA: CRC Press, 2013. p.435-448. 